\title{
ENGLISH VERSION: GALECTIN-3 AS A MARKER OF MYOCARDIAL FUNCTION IN MEN AGED 40-60 YEARS WITHOUT CARDIOVASCULAR PATHOLOGY, CARRIERS OF POLYMORPHIC GENES AT1R*
}

\author{
Ruzhanska V.O., Sivak V.G., Lozinska M.S., Zhebel V.M.
}

National Pirogov Memorial Medical University, Vinnytsia

The concentrations of galectin-3 and BNP, central and systemic hemodynamics, structural and functional heart parameters in male carriers of polymorphic AT1R genes without cardiovascular pathology $(n=79)$ living in Podillya region were studied. Genotyping of the ATIR gene was carried out using a polymerase chain reaction. The level of galectin-3 and $B N P$ was determined by the method of enzyme immunoassay. It was found that the A1166A genotype dominated in practically healthy men of Podilly region. Nevertheless, the level of galectin-3 and BNP in the studied population did not significantly depend on the carriage of a specific variant of the AT1R gene.

Key words: polymorphism of the gene of the angiotensin II receptor type (AT1R), galectin-3, brain natriuretic peptide, arterial pressure.

\section{Introduction}

The age structure of the heart, expansion of its chambers, reduction of the elasticity of the cardiac cells and decreased cardiac turnover, fluid retention and vascular remodeling, increasing the load on the left ventricle (LV), neurohumoral attack are some of the possible links to the pathogenesis of the heart failure, especially against the backdrop of cardiovascular disease, vascular pathology [13].

For doctors are around the world to find an effective screening tool for asymptomatic LV dysfunction, stratification of risk and general prognosis, quality of life serves as the subject of many scientific analyzes and discussions. One of the directions of such searches is the use of modern biomarkers for the state of myocardium. To date, a large number (over 100) of biomarkers have been identified as those, which that have a close relationship with the deterioration of the function of the myocardium, but the interpretation of such analyzes and their clinical significance is often insufficient.

Of these, in the clinical practice for the diagnosis of acute and exacerbation of chronic heart failure (CHF), the systems of subjects of natriuretic peptides (NUP), namely, the brain natriuretic peptide (BNP) is widely used. NUP - a group of circulating blood hormones that regulate water-salt homeostasis and blood pressure (BP).

In physiological conditions and in the formation of cardiovascular pathology, NUPs play an important role in the regulation of the structural and functional state of cardiovascular pathology. BNP is considered to be a cardiac hormone that regulates the amount of fluid in the body and BP, reduces preload and post-load on the heart. Its effect leads to an increase in the velocity of glomerular filtration, natriurea, blockade of the reninangiotensin-aldosterone system, suppression of spontaneous and induced angiotensin II thirst, inhibition of secretion of arginine and vasopressin, reduction of vasoconstrictive action of endothelin-1, as well as sympathetic innervation of blood vessels.

As a result, there is a decrease in pressure in the cavities of the heart, vascular tone, general peripheral resistance and $\mathrm{AH}$ [8]. Many studies have shown that activation of BNP synthesis occurs in patients with LV dysfunction, both with asymptomatic and clinically proven myocardial dysfunction, regardless of its cause [5]. A positive linear correlation between the level of BNP and end-diastolic pressure in the lungs [6] and the development of diastolic dysfunction of the myocardium [18] have been established, which allows BNP to be considered as a possible marker of the state function of the heart. However, at the same time, the prognostic value of this marker for stratification of risk is currently considered insufficient, therefore, in order to determine a more accurate prognosis in patients with myocardial dysfunction, it is advisable to use both the well-known use of known biomarkers and the search for new ones as well.

One such biomarker is galectin-3, representative of the family of gallets, is an inducer of macrophage migration, fibroblast proliferation and collagen synthesis. Galectin-3 may be one of the possible indications of heart failure syndrome, since it reflects the activity of the inflammation and fibrosis, is virtually not detected in cardiomyocytes, whereas myocardial fibroblasts express its high levels [17].

When it enters the myocardium, through the paracrine effect, it stimulates the rapid increase in myofibroblasts and the release of procologen 1 in the extracellular matrix, which leads to cardiac fibrosis [23]. Expression of galectin-3 has a reliable correlation with ejection fraction LV increases in patients with a reduced and preserved left ventricular ejection fraction, regardless to the etiology of myocardial dysfunction, when there are no clinical manifestations [16]. These data may indicate a more pronounced myocardial fibrosis in people with reduced $\mathrm{PV}$, which leads to progression of diastolic dysfunction of the lungs [4]. The level of galectin-3 in patients with CHF in the background of arterial hypertension was 1.5 times higher compared with patients without this [14]. In plasma, the level of galectin-3 most closely correlated with a high risk of cardiovascular mortality and rehospitalization in patients with CHF [20]. Galectin-3 has been approved as a biomarker with an independent prognostic value in patients with acute and chronic heart failure, and it can also be used to predict short-term (60day) mortality, since the MSI biomarker is used better for a long-term prognosis (4 years) [26 ] From 2013, galectin-3 is included in the current clinical agreement of the American Heart Association for the prevention and treatment of $\mathrm{CHF}$ as an additional marker for stratification of high-risk adverse clinical outcomes (death and readmission) [27].

The aforementioned pathological processes in the

* To cite this English version: Ruzhanska V.O., Sivak V.G., Lozinska M.S., Zhebel V.M. Galectin-3 as a marker of myocardial function in men aged 40-60 years without cardiovascular pathology, carriers of polymorphic genes AT1R // Problemy ekologii ta medytsyny. - 2018. - Vol 22, № 1-2. - P. 38-42. 
myocardium, the markers of which are BNP and galectin3 , are stimulated, as it is known, by norepinephrine, aldosterone and angiotensin II [7]. The latter implements its influence through AT1R, therefore, the polymorphism of the receptor shop can become a "conditional trigger" for regulating the level of BNP and galectin-3. The results of many experimental and clinical studies suggest that one of the main components in the pathogenesis of myocardial dysfunction is the activation of the components of the renin-angiotensin-aldosterone system (RAAS) and its effector hormone angiotensin II [12]. The AT1R gene is mapped in the 3rd chromosome (3q21-3q25), it contains 5 exons and today about 16 structural polymorphisms of this gene are described. However, it turned out that the polymorphism-substitution in position 1166 of adenine $(A)$ on cytosine $(C)$ was associated with the functional activity of AT1R [21].

For the representatives of the Podillya region in Ukraine, the association of development of AH with AT1R polymorphism among men 40-60 years is shown, during the researches it was determined that for carriers of allele $\mathrm{C}$, the probability of the development of the expressed eccentric LFS and diastolic heart dysfunction during the course of $\mathrm{AH}$ is significantly higher than for carriers only allele $A[3,9,11]$. The probability of getting hypertension in the presence of a patient's genotype A1166C increases 1.3 times [23]. Thus, finding possible associative changes in the carrier of polymorphic AT1R genes and levels of galetin-3 and BNP in patients without cardiovascular disease may be further based on these markers in predicting structural changes in the myocardium in patients with $\mathrm{AH}$ and $\mathrm{CHF}$ of similar age and sex.

Previously, such studies were not carried out in Ukraine. The article presents the first stage in the results form of the examination men of $40-60$ years without cardiovascular disease, inhabitants of the Podillya region in Ukraine.

The aim of the research was to study the level of biomarkers of galectin-3 and BNP in blood plasma and the corresponding state of structural and functional parameters of myocardium in men of $40-60$ years without signs of cardiovascular pathology, carriers of AT1R polymorphic genes.

\section{Materials and methods}

During the study, 79 men of 40-60 years without signs of cardiovascular disease living in the Podillya region were examined. The average age of the subjects was $57.06 \pm 0.50$ years. All men were examined at the Vinnytsia Regional Specialized Clinical Dispensary of Radiation Protection of the Population of the Ministry of Health of Ukraine and the Military Medical Clinical Center of the Central Region of the Air Force in Ukraine, and also were observed outpatient from December 2013 to July 2014. All men included in the study group at the time of examination complaint from the cardiovascular system did not present and did not have objective pathological signs. To determine the alleles of the polymorphic site (A1166C) of the AT1R gene, the polymerase chain reaction method was used. The genotyping of the AT1R gene was carried out in cooperation with the Scientific and Research Insti- tute of Genetic and Immunological Foundations of the Pathology and Pharmacogenetics of the VDNZU "Ukrainian Medical Dentistry Academy" (Poltava, head Professor Kaidashev IP). To determine the alleles of the polymorphic site (A1166C) of the AT1R gene, the genomic DNA was isolated from venous blood leukocytes.

The concentration of MNP in blood plasma in the subjects was determined using the immune enzyme method on the Humareader single-strip enzyme immunoassay analyzer (450 nm wavelength) and $630 \mathrm{~nm}$ differential filter. The standard set of Peninsula laboratories Inc. (USA) was used to determine the plasma concentration of BNP.

The concentration of galectin-3 in the blood plasma of the individuals was determined by the method of immunoassay analysis using the apparatus "Stat Fact 330 " at a wavelength of $450 \mathrm{~nm}$ and a differential filter of $630 \mathrm{~nm}$. A standard set of reagents from Bender MedSystems $\mathrm{GmbH}$ (Austria) was used to determine the plasma concentration of gallet-3. The frequency distribution of polymorphic genes in the population was checked in accordance with the Hardy-Weinberg equilibrium law with the help of the gene expert's calculator a number of statistical parameters in the case-control studies using SNP were calculated (the State Science Center of the Russian Federation "GosNII genetics", gen- exp.ru).

The evaluation of the parameters of systemic and intracardiac hemodynamics was performed using ultrasound of the heart, which was conducted on the echogram "Sim5000 Plus". The left ventricular myocardial mass (MMLF) is calculated using the Penn Convention formula, the left ventricular myocardial mass index ( $\mathrm{g} /$ m2) (IMMH). ECG registration was carried out according to the generally accepted method in 12 standard leads. Blood pressure measurements were performed according to WHO expert recommendations. The mathematical processing was performed on a personal computer using the standard statistic package STATISTICA 10.0.

\section{Results and Discussion}

In the selected population of individuals, the carrier frequency of different variants of the AT1R gene polymorphism was determined with the replacement of adenine with cytosine in 1166 position. It has been established that in male the frequency of the A1166A genotype of the AT1R gene is $62.03 \%(n=49)$, the genotype A $1166 \mathrm{C}$ is $30.38 \%(n=24)$, and the genotype C1166C is $7.59 \%(n=6)$ (paa-cc $\leq 0.05$; pac-cc> 0.05; pac-aa $\leq 0.05)$. In the study of the frequency distribution of alleles AT1R gene, it was found that among men without cardiovascular pathology, allele A occurs in $75.16 \%$ of the individuals, allele C - at $24.84 \%$. When comparing allelic frequencies of the AT1R gene, significant differences were found $(p<0.05)$.

Thus, in men without cardiovascular disease, the genotype A1166A of the AT1R gene dominates (Figure 1). A similar frequency of occurrence of polymorphic AT1R genes and alleles was noted among the inhabitants of Podillya [1, 2, 10, 11, 12]. 


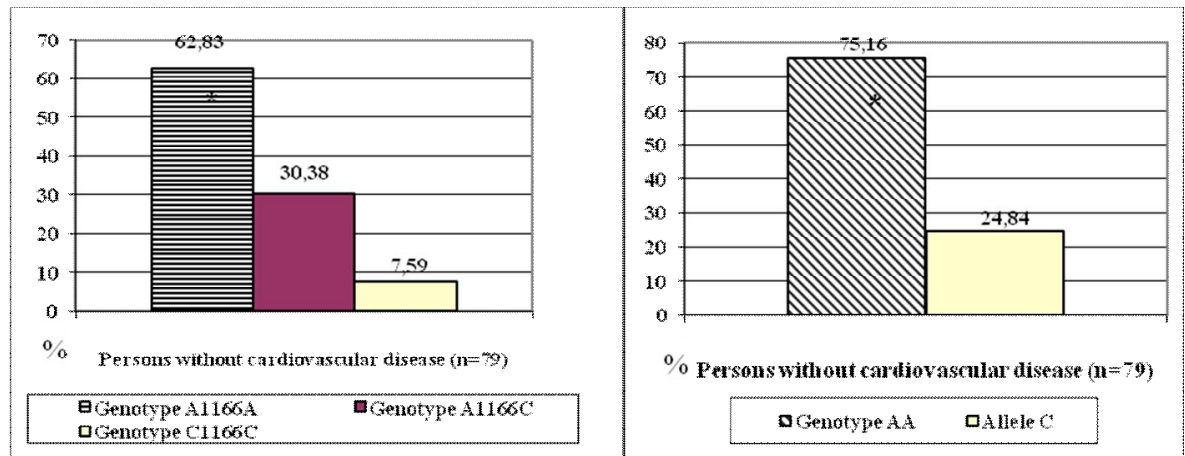

Figure 1. Distribution of the frequencies of the genotypes and alleles of the AT1R gene among men without cardiovascular pathology of 40-60 years old inhabitants of the Podillya region (\%).

Note: the difference between the indices is significant $(p \leq 0.05)$ when compared with:

* - the genotype A1166C / allele C within the group.

A similar relationship found in the inhabitants of Moscow allele $A$ and the genotype AA gene AT1R is found much more often in apparently healthy people [15]. Representatives of the French population of allele $A$ were also significantly more likely to be found among people without cardiovascular disease [25]. There is evidence that for the Japanese population, there is an association between the carriage of the CC genotype and the increased mass index of myocardial infarction both in normal blood pressure and in hypertensive individuals [24]. Correlation of carriers of the CC genotype with the development of $\mathrm{AH}$ was found in the Chinese population [19].

In Ukraine, also among Poltava residents, hypertonic patients were twice as likely to have genotypes of the AC and $\mathrm{CC}$, as the proportion of AA carriers was 4 times lower $(p \leq 0.05)$ compared with healthy individuals. A similar connection of the development of uncomplicated $\mathrm{AH}$ with polymorphism AT1R among men of mature age, residents of Vinnytsia region was followed in a study conducted by the staff of the Department of Internal Medicine of the Medical Faculty №2 of the VNMU named after M.I. Pirogov.

As with the inhabitants of Poltava, the residents of Vinnytsia showed a significantly higher prevalence of genotypes $\mathrm{A} 1166 \mathrm{C}$ and $\mathrm{C} 1166 \mathrm{C}$ and allele $\mathrm{C}$ in patients with $\mathrm{AH}$. Also, the association carriage of the genotype $\mathrm{A} 1166 \mathrm{C}$ and allele $\mathrm{C}$ in patients with $\mathrm{GC}$ with the formation of expressed EGLV, systolic and diastolic dysfunctions of the myocardium LV and the formation of $\mathrm{CHF}$ $[11,12]$ was established.

It is established that in women without cardiovascular pathology the genotype A1166A of the AT1R gene prevails, and the inheritance of women of postmenopausal

age of inhabitants of Vinnytsia and Vinnytsia region, the genotypes of the AT1R gene with the presence of allele $\mathrm{C}-\mathrm{A} 1166 \mathrm{C}$ and $\mathrm{C} 1166 \mathrm{C}$, is associated with a higher probability of the occurrence of CHF II A stage II-III FC for NYHA against the background of $\mathrm{AH}$ [10].

According to our data, the carriers of the genotype A1166A revealed a significantly lower frequency of encountered heredity compared to carriers of allele C (20.61\% and $83.33 \%$ respectively). Consequently, AT1R polymorphism is a factor that can be used to search for possible asymptomatic myocardial dysfunction associated with pathogenesis with RAAS activation. Accordingly, to what has been mentioned above, changes in the concentration of biomarkers reflecting the activity of antiRAAS (BNP) systems or the results of its effects are expected with such polymorphism. It depends on the structural morphology of the myocardium in particular on the processes in the connective tissue, which to a certain extent reflects the concentration of galectin-3. Taking into account the factors that may reflect the activation of RAAS, changes in the frequency of different categories occurrence of blood pressure (within the limits of "normal values") were investigated.

In carriers of allele A, optimal blood pressure is found in $26.03 \%$ (1), normal blood pressure is $49.32 \%$ (2), high normal blood pressure is $24.65 \%$ (3) (p2-1 <0.05, p3- 1> $0.05, \mathrm{p} 3-2<0.05)$. In carriers of the allele $\mathrm{C}$ optimal blood pressure is determined in $33.33 \%$ (1) men, normal blood pressure $-16.67 \%$ (2), high normal blood pressure - $50 \%$ (3) $($ p2-1 $<0.05, p 3-1>0.05, p 3-2>0.05)$. Consequently, in carriers of the allele $C$, high normal blood pressure is more likely to be detected than carriers of the allele $A$ of the AT1R gene $(p<0.05)$. (Figure 2$)$.

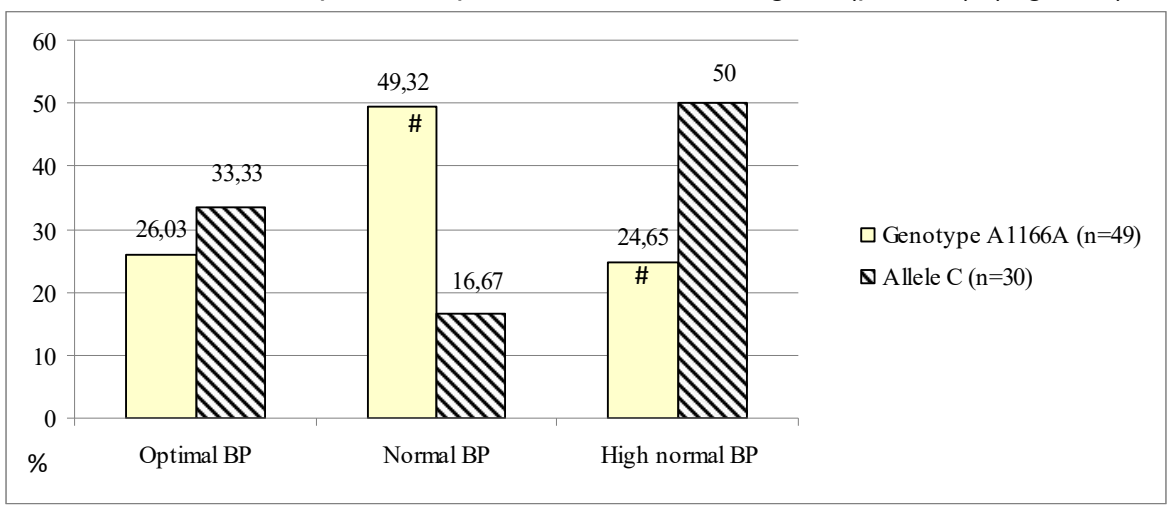

Fig. 2. Frequency of certain categories distribution of normal blood pressure in men without cardiovascular pathology of 40-60 years old inhabitants of the Podillya region, carriers of various alleles of the AT1R gene, (\%).

Notes: the difference between the indices is significant $(p<0.05)$ when compared with:

\# - the optimal BP within the group of carriers of the allele $C$ of the AT1R gene. 
As a result of the study, it was determined that the highest mean systolic blood pressure (SBP) was recorded with allele $C$.

Interesting is the fact that the level of galectin-3 in men without cardiovascular disease, with different cate- gories of normal blood pressure, was significantly different. In particular, the concentration of galectin- 3 in contrast to the content of BNP in individuals with normal and high normal blood pressure was higher than with optimal blood pressure (Fig.3).

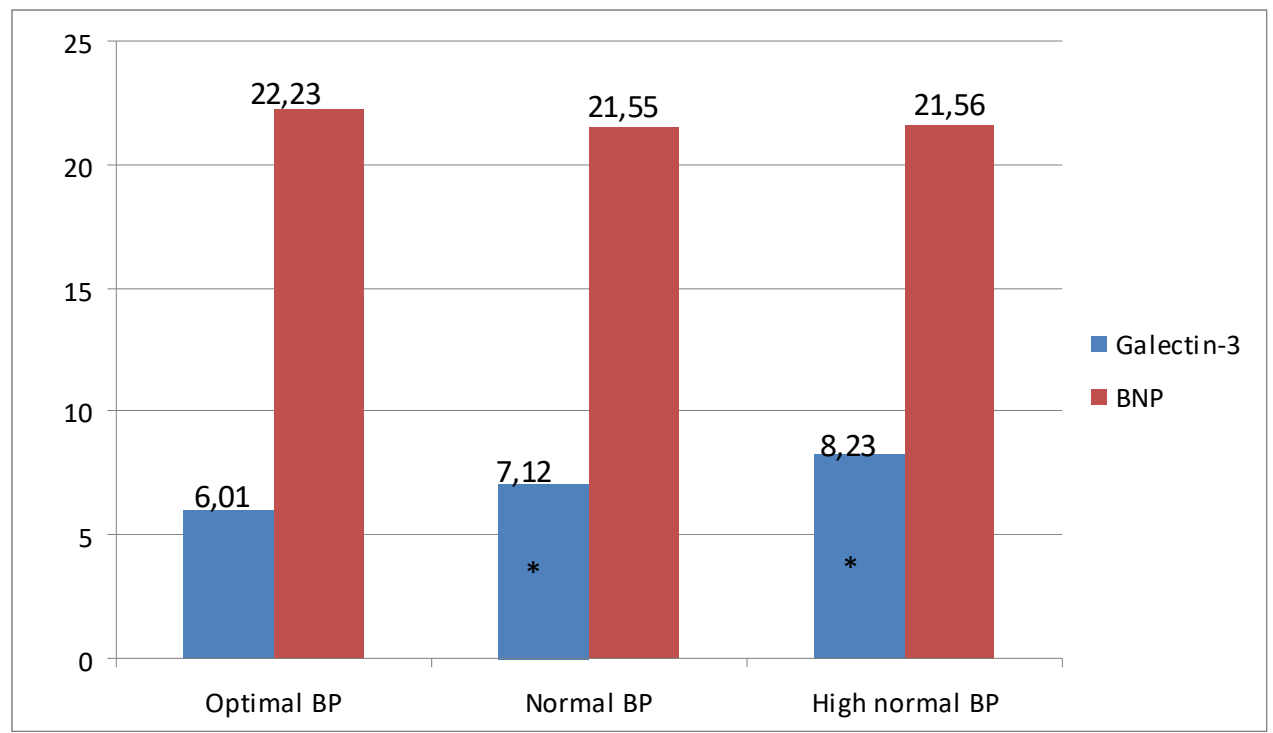

Fig. 3. Level of galectin-3 and cerebral sodiumuretic peptide in blood plasma in men without cardiovascular pathology, carriers of different genotypes of the AT1R gene in different categories of normal blood pressure $(\mathrm{ng} / \mathrm{ml}, \mathrm{pg} / \mathrm{ml})$.

Note: the difference between the indices is reliable ( $p \leq 0.05)$ when compared with:

* - within the group for different categories of blood pressure for the indicators of galectin-3.

According to the scientific literature, the known dependence of BNP concentrations in blood plasma and obesity in CHF was resolved to investigate plasma levels of galectin-3 and BNP in men without cardiovascular pathology at different body mass index. There was no significant difference in the levels of BNP in the presence or absence of obesity ( $p>0.05)$, which corresponds to the results of previous studies [1].

Unlike BNP, the level of galectin-3 with excess body weight was - $(7.31 \pm 0.27) \mathrm{ng} / \mathrm{ml} \quad(n=29)$, and at normal body weight $-(6.40 \pm 0.36) \mathrm{ng} / \mathrm{ml}(n=50)(p<0.05)$. Thus, in conducting research using the gallet-3, one must take into account the phenomenon which was found.

\section{Conclusions}

1. Among the men who inhabit the Podillya region of Ukraine aged 40-60 years without cardiovascular pathology, the genotype A1166A of the AT1R gene prevails.

2. The level of galectin-3 and BNP in the studied population did not significantly depend on the carrier of a particular variant of the AT1R gene.

3 . The concentration of galectin-3 in men without signs of cardiovascular disease with normal and high normal blood pressure was higher than with optimal blood pressure.

4. The level of galectin-3 in contrast to BNP in blood plasma is higher with excessive body weight.

\section{Prospects for further studies}

1. It is very relevant to study the phenotypic markers, as the most simple, available and acceptable in the doctor's practice criteria for the risk of $\mathrm{AH}$ development.

2. Certainly, the question arises about changes in the concentration of galletin-3 in combination with BNUP when inheriting various variants of AT1R, taking into account the association of the latter with the same proc- esses in the myocardium, which may depend on the content of plasma in the blood of this biomarker.

\section{References}

1. Blanar O. L. Spadkovist' ta strukturno-funkzional'ni zmini serzya u chvorich na gipertonichnu chvorobu, usklad-nenu serzevoyu nedostatnistyu // Simeyna medizina. - 2009. № 2. - S. 79-85.

2. Gefter, Yu.O. Stan miokardu u chvorich na gipertonichnu chvorobu v zalezhnosti vid variantu genotipu rezeptoriv angiotenzinu II 1-go tipu ta nayavnosti sudinnich uskladnen' // Galiz'kiy visnik. - 2006. - № 1 (13). - S. 20-24.

3. Drapkina, O. M. Primenenie biologicheskich markerov $v$ diagnostike diastolicheskoy serdechnoy nedostatoch-nosti // Zhurnal Serdechnaya nedostatochnost'. - №12 (6). S. 364-372.

4. Kovalenko V.M., Kamins'kiy O.G. Akademik M.D.Strazhesko i rozvitok vitchiznyanoï kardiologiï ta re-vmatologiï. - 2001: Kiïv. MORION.

5. Kovalenko V.M., Kornaz'kiy V.M. Dinamika stanu zdorov'ya narodu Ukraïni ta regional'ni osoblivosti. 2009, Analitichno-statistichniy posibnik. Kiïv. Medinform.

6. Kovalenko V.N., Talaeva T.V. Serdechno-sosudistye zabolevaniya i renin-angiotenzinovaya sistema.- 2013, Kiïv. Morion.

7. Kornaz'kiy V.M., Dorogoy A.P., Manoylenko T.S. Serzevo-sudinna zachvoryuvanist' v Ukraïni ta rekomendaziï schodo pokraschannya zdorov'ya v suchasnich umovach. -2012 , Kiïv.

8. Lozins'kiy, S.E. Rol' polimorfizmu A1166S gena re-zeptoriv do angiotenzinu-II pershogo tipu (ATR1) u vi-niknenni arterial'noï gipertenziï ta gipertrofiï livogo shlunochka u meshkanziv Podillya // Obschaya medizina. - 2012. -№ 5. - S. 87-101.

9. Sakovich O. O. Uspadkuvannya polimorfnich genotipiv gena rezeptora angiotenzinu II 1-go tipu ta faktori ri-ziku rozvitku gipertonichnoï chvorobi u zhinok, yaki prozhivayut' u Vinniz'kiy oblasti // Zaporozhskiy medizins-kiy zhurnal. - 2011. - №4 (13). S. 44-47.

10. Starzhins'ka, O.L. Osoblivosti perebigu gipertonichnoï chvorobi u cholovikiv z riznimi genotipami rezeptora 
ToM 22, N 1-2 2018 p.

angiotenzinu II 1-go tipu // Biomedical and Biosocial Antropology/ - 2005. - №4. - S. 171-177.

11. Starzhins'ka O.L. (2013). Polimorfizm geniv reninangiotenzin-al'dosteronovoï sistemi v kardiologiï. // Biomedical and biosocial anthropology. - 2013. - № 20. - S. 204-207.

12. Tokar', A.V., Ena L.M. Arterial'naya gipertenziya v pozhilom i starcheskom vozdaste. 1989, Kiev. Zdorov'e.

13. Zeluyko, V.Y. Galektin-3 u chvorich na chronichnu serzevu nedostatnist' // Ukraïns'kiy kardiologichniy zhurnal. - 2014. - № 3. -.S. 77-81.

14. Chistyakov D.A. Polimorfizm gena sosudistogo rezep-tora angiotenzina II i sedechno-sosudistye zaboleva-niya // Terapevticheskiy archiv. - 2000. - № 4. - S. 27-30

15. De Boer R.A. Galectin-3: a novel mediator of heart failure development and progression // Eur J Heart Fail. -2009. №11, 811-817.

16. De Filippi, C.R. Galectin-3 in heart failure - linking fibrosis, remodeling, and progression. US // Cardiology. - 2010. Vol.7. - P. 67-70.

17. Edelmann, F. Galectin-3 in patients with heart failure with preserved ejection fraction: results from the Aldo-DHF // European Journal of Heart Failure. - 2015. - Vol.17. - P. 214-223.

18. Feng, X. A systematic review and meta-analysis of the association between angiotensin II type 1 receptor A1166C gene polymorphism and myocardial infarction suscepyibility // Journal of Renin-Angiotensin-Aldosterone System. - 2012. - Vol.23. - P. 1-9.

19. Milting, H. (2008). Plasma biomarkers of myocardial fibrosis and remodeling in terminal heart failure patients sup- ported by mechanical circulatory support devices // J Heart Lung Transplant. - 2008. - Vol.27. - P. 589-596.

20. Poirier, O. (1998). New polymorphisms of the angiotensin II type 1 receptor gene and their associations with myocardial infarction and blood pressure: the ECTIM study. Etude Cas-Temoin de I'Infarctus du Myocarde // J. Hypertens. -1998. - Vol.10. - P.- 1443-1447.

21. Roig E.(2000). Clinical implications of increased plasma angiotensin II despite ACE inhibitor therapy in patients with congestive heart failure. // Eur Heart J. - 2000 Vol.21(1). - P. 53-57.

22. Suarez, G. Heart failure and galectin 3. // Annals of Translational Medicine. - 2014. -Vol. 2 (9). - P. 86-92.

23. Takami, S. Angiotensin II type 1 receptor gene polymorphism is associated with increase of left ventricular mass but not with hypertension. // Am. J. Hypertension. -1998. Vol. 11. - P. 316-321.

24. Tiret L.,Blanc H., Ruidavets J.B. et al. Gene polymorphisms of the rennin-angiotensin system in relation to hypertension and parental history of myocardial infarction and stroke: PEGASE study. Project d'Etude des Genes de l'Hypertension Arterielle Severe a Moderee Essentielle // J Hypertens.-1998.- Vol.16. - P. 37-44.

25. E.Wilson Grandin. Galectin-3 and the Development of Heart Failure after Acute Coronary Syyndrome: Pilot Experience from PROVE IT-TIMI 22. // Clinical Chemistry. 2012. - Vol. 58(1). - P. 267-273.

26. Yancy C.W. 2013 ACCF/AHA guideline for the management of heart failure: a report of the American College of Cardiology Foundation/American Heart Association Task Force on Practice Guidelines. // J. Am. Coll. Cardiol, 2013. - Vol.62(16). - P. 147-239. 